\title{
THE SOILS OF BOTEVGRAD VALLEY
}

\author{
Biser Hristov
}

\begin{abstract}
The paper deals with Botegrad valley soil cover, properties, conditions and vegetation. The soil cover in the Botevgrad region is characterized by considerable diversity in the ravine valleys of the Bebresh River and its tributaries. Alluvial and Diluvial soils occur in the middle of the region in lowest parts. Gray forest soils developed in the PreBalkans and the northern slopes of the Balkan Mountains and Light Gray forest soils (Pseudopozolic soils) are spread there too. The most fertile soils are Dark gray forest soils but only in limited area. Shallow soils (Lithosols), are widely spread over reddish-brown quaternary materials, characterized by the presence of many skeletal particles. The soil cover on the slopes is eroded, cut by deep ditches, ravines and valleys.

Main part of the land in the valley is cultivated. Arable lands for cultivation and pastures are about $68.4 \%$, other $22 \%$ are used for mainly for forestry. Settlements, industrial zones and other infrastructure occupy $9 \%$ of the valley.
\end{abstract}

Key Words: soil cover, soil property, Botevgrad valley

\section{INTRODUCTION}

The Botevgrad valley is a basin depression in the Western Fore-Balkan, located between the Billo and Murgash Mountains to the south, the Big Mountain to the southwest, and the Rzhana Mountain to the northwest, which are parts of the Western Balkan
Range. To the north and northwest, the valley rests on the slopes of the mountain ridges Gola Glava and Lakavitsa, parts of the Pre-Balkan. In the village of Razliv through the low threshold Lopatna, the valley is divided into two parts - in the west by the real Botevgrad valley, and in the east by the small Pravets valley (Photo 1 and Fig.1).

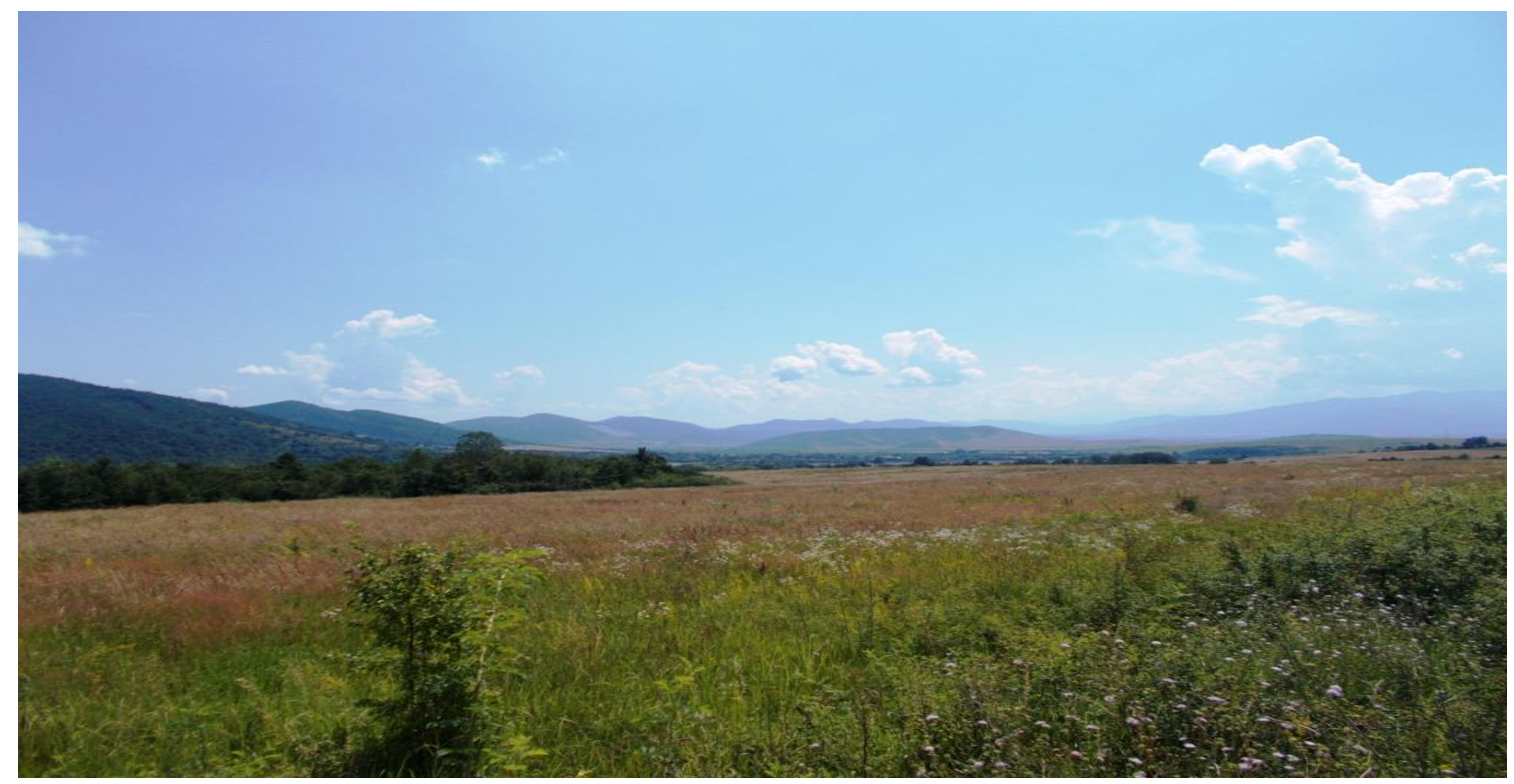

Photo 1. Botevgrad Valley

Along the southern periphery of the valley passes the boundary between the Fore- Balkan to the north and the Balkan Mountains to the south. The entire length of the valley from northwest to southeast is 28$30 \mathrm{~km}$ and its maximum width is about $12 \mathrm{~km}$. The total area is $150 \mathrm{~km}^{2}$. The valley floor lies on $320-420$ $\mathrm{m}$ of altitude, slightly sloping to the north, filled with alluvial deposits and partially damped in the central part. In the middle of the valley rise several inland hills: Medven (520 m), Temusha (480 m), Litakovski hills (417 m) and others. Large alluvial cones occupy the southern outskirts of the valley rising to the Balkan Mountains. There are 12 settlements in the Botevgrad valley, include 2 cities Botevgrad and Pravets and 10 small villages $[1,2]$.

The soil cover in the Botevgrad region is characterized by considerable diversity in the ravine valleys of the Bebresh River and its tributaries. Alluvial and Diluvial soils occur in the middle of the region in lowest parts. Gray forest soils developed in the Pre-Balkans and the northern slopes of the Balkan Mountains and Light Grey (Pseudopozolic) soil are 
spread there. Rednzinas and shallow soils (Lithosols) are developed over hills and slopes. The most fertile soils are Dark grey forest soils (Phaeozems) but only in limited area (Table 10 and Fig. 2).

According to Dotseva et al. [3], the Botevgrad basin is one of the numerous Late PlioceneQuaternary basins developed over the Balkanide orogen. The basin is developed in the West Balkan tectonic zone and on the northern slopes of the Stara
Planina Mountain along the Plakalnitsa fault zone (Botevgrad valley), the front of the orogen. In general, the Botevgrad basin is develop over the preAlpine basement, which is composed of low-grade metamorphites and intruded into them syn- to postVariscan granitoids. In the NW parts of the basin boards, Late Carboniferous and Permian terrestrial, non-metamorphosed coarse-grained deposits and volcanic rocks.

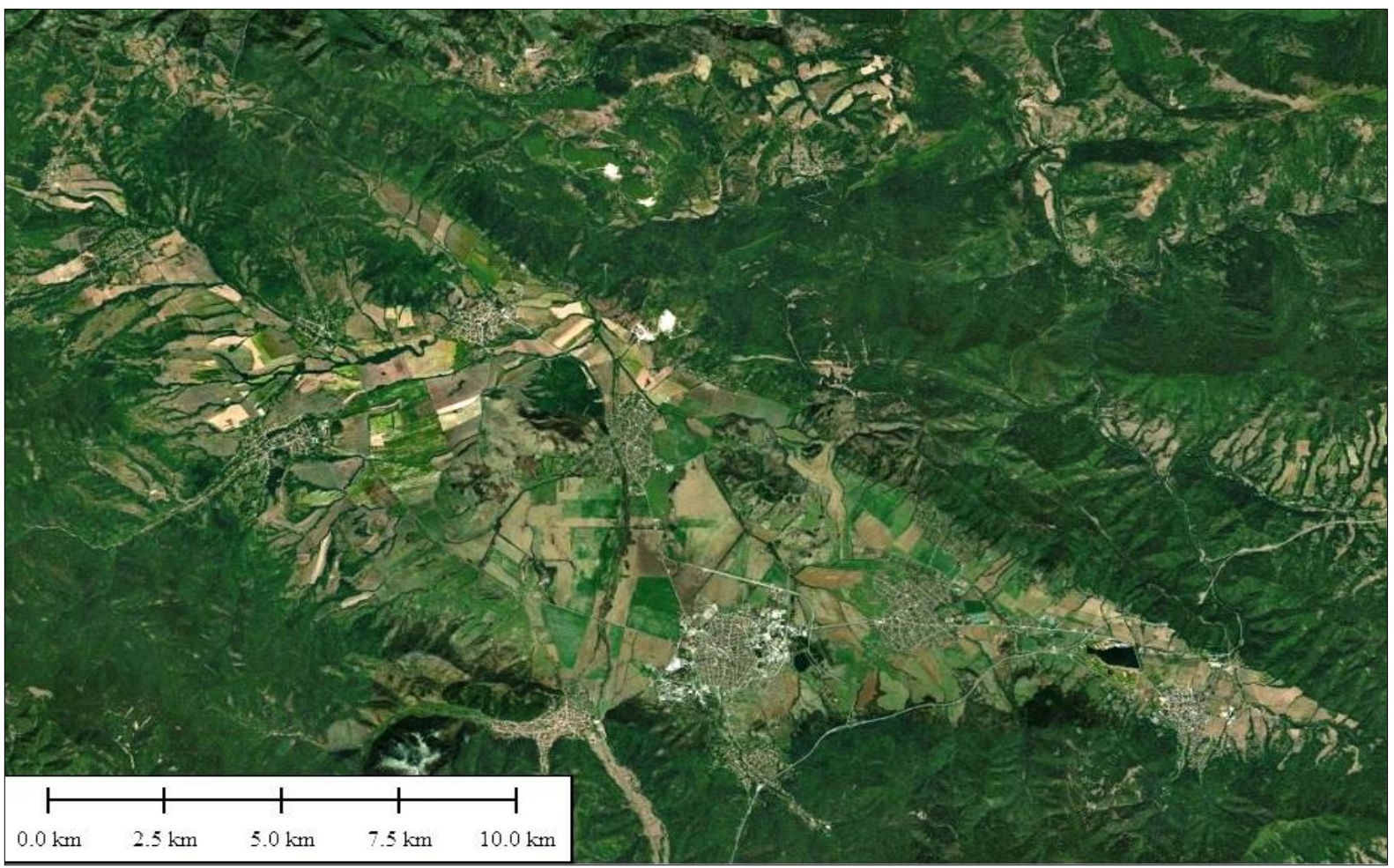

Fig 1. Satelite image of Botevgrad valley. District of Sofia, Bulgaria.

Botevgrad Valley is a part of Fore-mountainous climatic region, which is under the direct influence of Stara Planina Moutain. The climate is temperate and during the winter season often observed temperature inversions. The average annual temperature is $10-11^{\circ} \mathrm{C}$, and annual rainfall - about $680 \mathrm{~mm}$. This summer rains are very intense, and exceeds almost twice the winter. Altitude (600 $800 \mathrm{~m}$ ) is the cause for a relatively cool summer. The average monthly minimum temperature gives an indication of the average range (in a month), between which oscillates the air temperature during the day. [1]

Main part of the land in the valley is cultivated. Grown cereals, vegetables fruit and southern slopes of the ridge Lakavitsa are occupied by vineyards. Swampy and wet areas are used for grazing. The valley is used for agricultural crops such as: maize (early hybrids), beans, soybeans, sunflower, beetroot, tobacco, wheat, alfalfa, flax, oats, potatoes, vetch and others.

\section{MATERIALS AND METHODS}

Soil properties information is taken form:

1) Soil characteristics of the land of Pravets [4];

2) Soil characteristics of the land of Botevgrad [5];

3) Soil characteristics of the land of Litakovo [6];

Soils are classified according Bulgarian classification [7] and WRB [8].

Soil map was created by ArcGIS 10; Satelite image by Global mapper 16; MS Office 10 was used for graphic statistics.

The aim of this study is to identify the distribution of major soil types, as well as the in order to facilitate the planning and implementation of activities related to utilize soil cover. 


\section{RESULTS AND DISCUSSION}

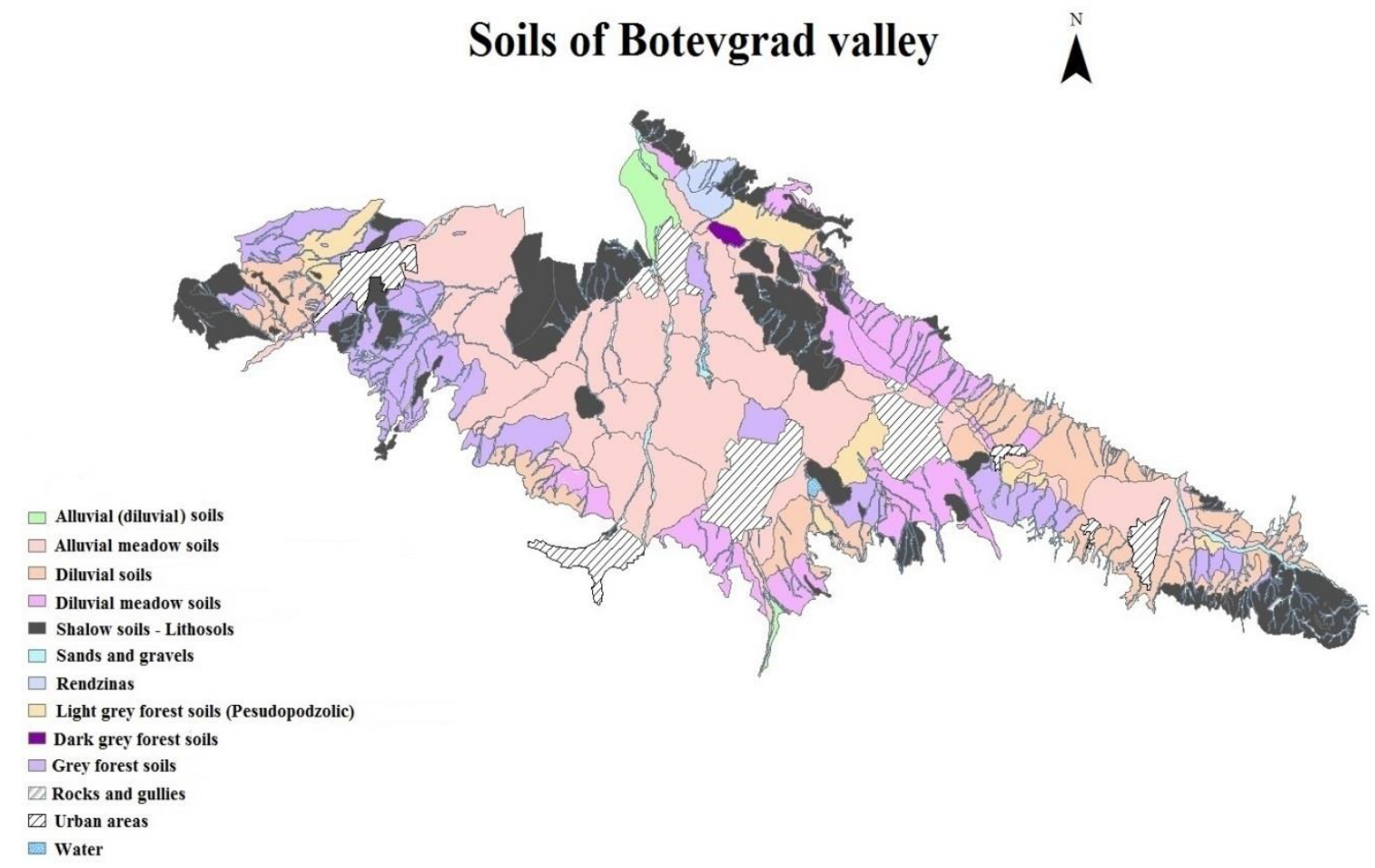

Fig 2. Soil map Botevgrad valley, District of Sofia, Bulgaria.

\section{Grey forest soils}

Gray forest soils are typical for Fore-moutanin area and the north and south part of Bottevgrad valley. These soils are spread in the area of transitional continental climate, which combines elements of Eastern European climatic influence of Central Europe. Annual rainfall varies from 550 to $700 \mathrm{~mm}$ with a clear tendency to increase with increasing altitude. Such climatic conditions create periodically washing water regime [9].

Historical data show that in the past the Gray forest soils were covered with forests, which dominated had tree species: oak, beech-tree, hornbeam, silver linden, field maple and others. Due to the economic activity much of the forest vegetation is destroyed. The remaining forests are relatively rare dominated by herbaceous vegetation.

The landscape of the region is crossed by deep river valleys and ravines, resulting in natural drainage is good. Groundwater is at greater depths. Soil formation rocks are different. In the Foremountain predominate Calcareous materials (marl, limestone, lime sandstone, etc.).

Gray forest soils are characterized by the following features: the intensive formation of clay in the soil profile (internal soil lessive process), profile differentiation of soil texture, without modifications of the chemical and mineralogical composition of the colloidal fraction, Siallitic-agrillaceous type of weathering, specific character of humus formation and surface waterlogging profile of some subtypes [10]. For these reasons, gray forest soils are divided into three subtypes: Dark gray, Gray and Light gray forest soils. The most widespread are Gray forest soils, followed by Light gray and Dark gray forest soils.

Dark Grey Gorest soils - Phaeozems [7,8].

Compared to the gray and light gray forest soils, dark gray is with deeper humus horizon (up to $45 \mathrm{~cm}$ ), with fine granular structure. The subsurface argic horizon has a different deep (most often 80 to $110 \mathrm{~cm}$ ). Colored usually in brown with yellow spots, often with a reddish tinge. It has a heavy clay soil texture and dense. The soil structure is lumpy-prismatic. The transition between humus and argic horizon is relatively gradual. Whetered " $\mathrm{C}$ " horizon is usually calcareous, slightly compacted, with lumpy structure or no coherent structure and significant content of the solid calcareous concretions (Table 1). 
Table 1. Soil properties of Dark Grey Forest soil - Phaeozem

\begin{tabular}{|c|c|c|c|c|c|c|c|c|c|c|c|c|}
\hline \multirow[b]{2}{*}{$\begin{array}{c}\text { Horizon } \\
\text { Depth }(\mathrm{cm})\end{array}$} & \multirow{2}{*}{$\mid \begin{array}{c}\text { Soil Color } \\
\text { (Munsell } \\
\text { Color } \\
\text { chart) }\end{array}$} & \multirow{2}{*}{$\underset{(\mathrm{KCl})}{\mathrm{pH}}$} & \multirow[b]{2}{*}{$\begin{array}{c}\text { SOM } \\
\text { (Humus) } \\
\%\end{array}$} & \multirow[b]{2}{*}{$\begin{array}{c}\text { Total } \\
\mathrm{CaCO}_{3} \\
\%\end{array}$} & \multirow[b]{2}{*}{$\begin{array}{c}\text { Total N } \\
\%\end{array}$} & \multicolumn{7}{|c|}{ Soil Texture - Particle size in $\mathrm{mm}$} \\
\hline & & & & & & $>1$ & $\begin{array}{c}1- \\
0.25\end{array}$ & $\begin{array}{l}0.25- \\
0.05\end{array}$ & $\begin{array}{c}0.05- \\
0.01\end{array}$ & $\begin{array}{l}0.01- \\
0.005\end{array}$ & $\begin{array}{c}0.005- \\
0.001\end{array}$ & $>0.001$ \\
\hline Ap $0-28$ & 10 YR $3 / 3$ & 4.7 & 2.26 & 0.0 & 0.147 & 0.0 & 3.8 & 13.4 & 26.5 & 13.3 & 16.2 & 25.0 \\
\hline ABt $28-57$ & 10 YR $5 / 3$ & 5.4 & 1.41 & 0.0 & 0.098 & 0.0 & 1.1 & 17.6 & 14.2 & 17.6 & 15.7 & 32.3 \\
\hline Btg 57-88 & $\mid 10$ YR $5 / 2 \mid$ & 5.4 & 0.88 & 0.0 & - & 0.0 & 0.6 & 10.9 & 18.4 & 12.1 & 26.5 & 29.7 \\
\hline Btg $88-120$ & 10 YR 5/2 & 5.4 & - & 0.0 & - & 0.0 & 1.7 & 12.7 & 17.9 & 14.4 & 14.8 & 36.9 \\
\hline Ck120 150 & 10 YR $6 / 1$ & 7.0 & - & 14.07 & - & 0.0 & 0.0 & 9.8 & 24.9 & 14.9 & 9.9 & 22.2 \\
\hline
\end{tabular}

Generally, dark gray forest soils have heavy clay texture. The contents of clay ranges between $22-37 \%$ $(>0.001 \mathrm{~mm})$. These soils contain the highest percentage of organic matter than other subtypes of gray forest soils. The content of humus in the A horizon ranges from 2.0 to $3.0 \%$, and generally progressively decreases in depth of the profile. The content of total nitrogen is 0.11 to $0.12 \%$. Carbonates are leached usually at a depth of $100 \mathrm{~cm}$. The reaction was slightly acidic in noncarbonate horizons and weakly alkaline in the carbonate lower horizons. Total porosity in the suffuse horizon is higher (40-45\%) and lower in argic horizon (20-25\%).

\section{Gray forest soils - Luvisols [7, 8].}

Gray forest soils occupy rised mountain plateaus and slopes of the region. The involvement of forest vegetation in their formation is more pronounced than in Dark gray forest soils. They were formed in different age and over diferent parent rock. These soils are characterized by the following features: a shalow surface and deep argic horizon, which is much better formed in comparison with the dark gray forest soils [4,12]. It has a thickness form 80 to $120 \mathrm{~cm}$ and lumpy-prismatic structure. There is accumulation of manganese nodules.

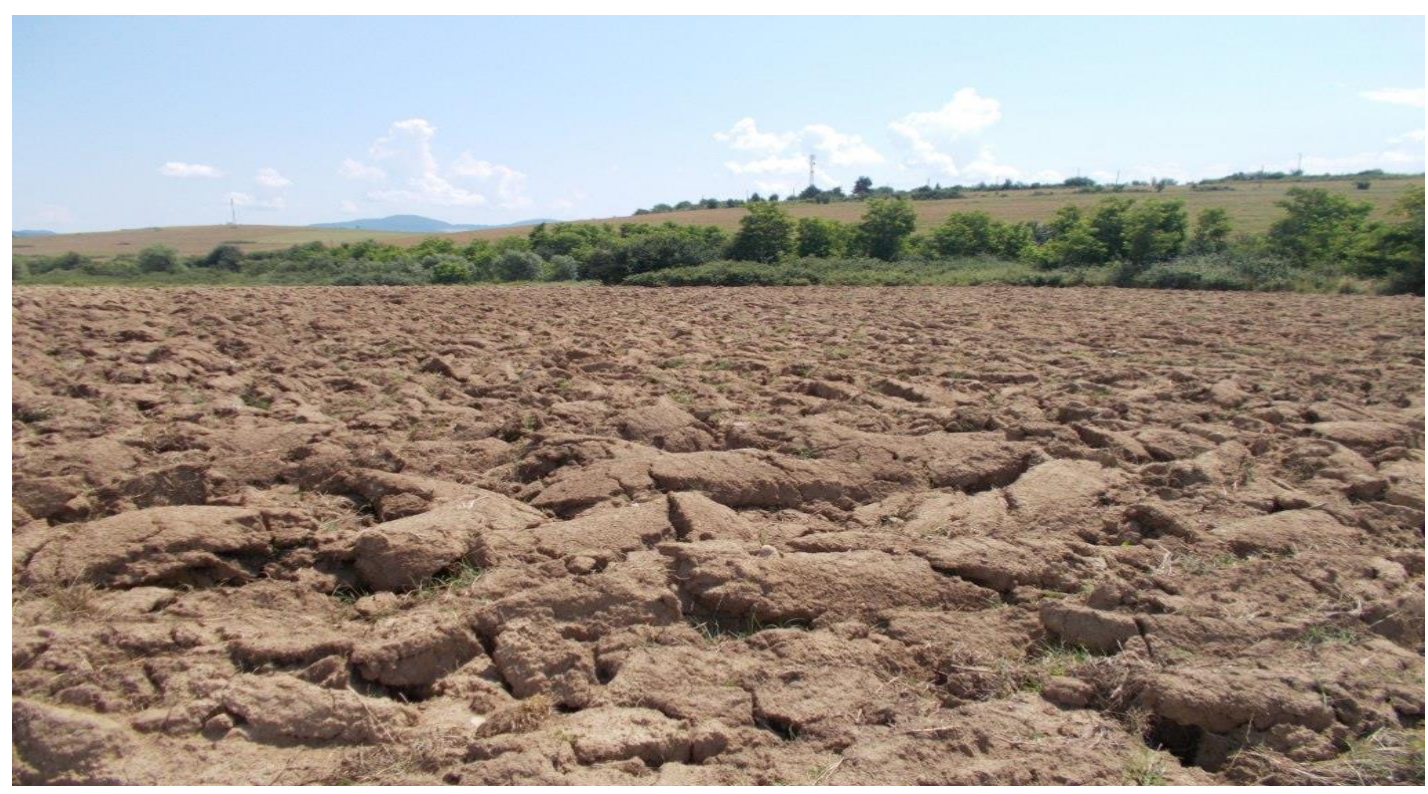

Photo 2. Grey forest soil, Botevgrad valley.

The soil texture is characterized by welldefined textural differentiation, content of clay is high in argic horizon than in surface horizon.
Clay removal under the influence of higher rainfall and humidity causes processes of lessivation. 
Table 2. Soil properties of Gray forest soils - Luvisols

\begin{tabular}{|c|c|c|c|c|c|c|c|c|c|c|c|c|}
\hline \multirow{2}{*}{$\begin{array}{c}\text { Horizon } \\
\text { Depth }(\mathrm{cm})\end{array}$} & \multirow{2}{*}{$\begin{array}{c}\text { Soil Color } \\
\text { (Munsell } \\
\text { Color } \\
\text { chart) }\end{array}$} & \multirow{2}{*}{$\begin{array}{c}\mathrm{pH} \\
(\mathrm{KCl})\end{array}$} & \multirow[b]{2}{*}{$\begin{array}{c}\text { SOM } \\
\text { (Humus) } \\
\%\end{array}$} & \multirow[b]{2}{*}{$\begin{array}{c}\text { Total } \\
\mathrm{CaCO}_{3} \\
\%\end{array}$} & \multirow[b]{2}{*}{$\begin{array}{c}\text { Total N } \\
\%\end{array}$} & \multicolumn{7}{|c|}{ Soil Texture - Particle size in $\mathrm{mm}$} \\
\hline & & & & & & $>1$ & $\begin{array}{c}1- \\
0.25\end{array}$ & $\begin{array}{c}0.25- \\
0.05\end{array}$ & $\begin{array}{c}0.05- \\
0.01\end{array}$ & $\begin{array}{l}0.01- \\
0.005\end{array}$ & $\begin{array}{c}0.005- \\
0.001\end{array}$ & $>0.001$ \\
\hline Ap 0-30 & $10 \mathrm{YR} 5 / 3$ & 3.9 & 1.83 & 0 & 0.105 & 2.6 & 9.2 & 21.7 & 21.3 & 9.9 & 15.3 & 19.1 \\
\hline ABt 30-60 & $10 \mathrm{YR} 4 / 4$ & 4.6 & 0.98 & 0 & 0.07 & 0.0 & 6.5 & 15.7 & 24.6 & 10.9 & 12.7 & 29.9 \\
\hline Btg2 60-89 & $5 \mathrm{YR} 4 / 4$ & 4.3 & 0.66 & 0 & - & 0.0 & 5.7 & 17.1 & 23.4 & 8.5 & 13.3 & 31.2 \\
\hline Btg3 89-130 & $5 \mathrm{YR} 4 / 4$ & 4.3 & 0.63 & 0 & - & 0.0 & 5.8 & 20.2 & 21.3 & 11.1 & 8.8 & 32.2 \\
\hline Btg4 130-160 & $5 \mathrm{YR} 4 / 4$ & 4.3 & 0.51 & 0 & - & 0.0 & 8.3 & 19.4 & 17.9 & 12.4 & 11.5 & 28.7 \\
\hline C1 160-190 & 5 YR 4/4 & 4.4 & 0.42 & 0 & - & 6.3 & 10.5 & 22.4 & 22.5 & 8.4 & 10.0 & 19.4 \\
\hline
\end{tabular}

Gray forest soils are characterized by low humus content (about $2 \%$ in the cultivated soils and from 4 to $7 \%$ in uncultivated). The greater content of the organic matter is concentrated in the surface horizon (Table 2). The carbonates are deeply washed. The reaction is moderately acidic $(\mathrm{pH}-3.9-4.5)$.

Bulk density shows bright differentiation in argic horizon with much higher values. Total porosity was higher on the top and decreased in argic horizon. These soils have relatively high waterlogging and low permeability.

Light gray (Pseudopodzolic) forest soils Planosols [7,8].

Light gray (pseudopozolic) soils are typical in a flattened and the depression forms. They were formed under the influence of deciduous forest (oak trees) and herbaceous vegetation, mainly on non-carbonate or weakly carbonate heavy or medium silty-clay materials over various massive rocks [12]. They can be low, medium or high surface waterlogged. Wet waterlogged Light gray forest soils (pseudoposozic) is usually defined as pseudogeyic.

Pseudogley has developed due to seasonal waterlogging together with alteration of reduction and oxidation conditions. Soils with pseudogley pattern occurrence during the wet period are characterized by anaerobic conditions and excess of moisture; during the dry period the leakage water disappears and drought affects plants [13].

Surface albic horizon is 20 to $40 \mathrm{~cm}$ deep. It is loose to dense dry and contains manganese nodule. Soil texture is lighter than in argic horizon. In AE and $\mathrm{E}$ surface horizons is observed loss of silicate clay, iron, aluminum, or some combination of these, with high a concentration of sand and silt particles (Table 3).

Table 3. Soil properties of Light gray forest soils - Planosols

\begin{tabular}{|c|c|c|c|c|c|c|c|c|c|c|c|c|}
\hline \multirow[b]{2}{*}{$\begin{array}{l}\text { Horizon } \\
\text { Depth }(\mathrm{cm})\end{array}$} & \multirow{2}{*}{$\begin{array}{c}\text { Soil Color } \\
\text { (Munsell } \\
\text { Color } \\
\text { chart) }\end{array}$} & \multirow{2}{*}{ } & \multirow[b]{2}{*}{$\begin{array}{c}\text { SOM } \\
\text { (Humus) } \\
\%\end{array}$} & \multirow[b]{2}{*}{$\begin{array}{c}\text { Total } \\
\mathrm{CaCO}_{3} \\
\%\end{array}$} & \multirow[b]{2}{*}{$\begin{array}{c}\text { Total N } \\
\%\end{array}$} & \multicolumn{7}{|c|}{ Soil Texture - Particle size in mm } \\
\hline & & & & & & $>1$ & $\begin{array}{c}1- \\
0.25\end{array}$ & $\begin{array}{c}0.25- \\
0.05\end{array}$ & $\begin{array}{c}0.05- \\
0.01\end{array}$ & $\begin{array}{l}0.01- \\
0.005\end{array}$ & $\begin{array}{c}0.005- \\
0.001\end{array}$ & $>0.001$ \\
\hline AEp 0-30 & $10 \mathrm{YR} 7 / 2$ & 4.2 & 2.63 & 0.0 & 0.132 & 6.8 & 2.9 & 22.5 & 32.4 & 12.3 & 4.7 & 17.9 \\
\hline E1 30-60 & $10 \mathrm{YR} 4 / 2$ & 3.9 & 0.69 & 0.0 & 0.036 & 0.0 & 6.7 & 21.8 & 28.3 & 13.2 & 11.2 & 18.5 \\
\hline B2tg $60-89$ & 10 YR 4/2 & 3.9 & 0.84 & 0.0 & - & 3.7 & 2.1 & 9.8 & 20.6 & 9.6 & 18.8 & 34.2 \\
\hline B3tg 89-130 & 10 YR 5/3 & 5.5 & 0.75 & 0.0 & - & 8.6 & 2.7 & 15.9 & 19.7 & 10.4 & 9.4 & 31.8 \\
\hline B4tg130-160 & 10 YR 4/4 & 5.9 & 0.99 & 0.0 & - & 10.2 & 5.6 & 8.0 & 21.3 & 10.6 & 8.7 & 24.5 \\
\hline C1 160-190 & 10 YR 4/4 & 5.7 & 0.64 & & & 7.7 & 5.4 & 21.2 & 21.8 & 9.4 & 7.5 & 25.7 \\
\hline
\end{tabular}

Light gray forest soils have a low organic matter content in the surface layer, in the cultivated area 1.6 to $1.8 \%$ and in the forest up to $2-3 \%$. In argic horizon quantity of humus is sharply reduced (less than 1\%). In accordance with the content and distribution of humus in the soil profile is located 
and the amount of total nitrogen. The reaction of the soil is acidic ( $\mathrm{pH}$ 3.9-5.9). There is an abrupt textural change between $\mathrm{E}$ and Btg horizons - fine clay from 18.5 to $34.2 \%$ (Table 3 ).

The deep, dense and clay argic horizon gives extremely unfavorable properties of Light gray forest soils. Its low permeability causes surface waterlogging in the wet seasons, the process water stagnation. Soils with a coarse-textured surface horizon abruptly over a dense and finer textured subsoil, typically in seasonally waterlogged flat lands [8].

Light grey forest soils areas occupy grass vegetation, often with shrubs and trees that have shallow root systems and can cope with temporary waterlogging. These soils are suitable for grazing and forestry.

\section{Rendzinas - Rendzic Leposols [7,8].}

Rendzinas are soils developed on calcareous rocks. They are mainly distributed in foothill and mountain areas and are subjected to varying degrees of erosion. In soil map Rendzinas are shown as a separate soil type and complex eroded and shallow Gray forest soils. In this area the most widespread shallow Rendzinas have a total thickness of up to 20-30 cm (Table 4).

Rendzinas are soils with low profile depth of 30 to $50 \mathrm{~cm}$. More power $(60-100 \mathrm{~cm})$ soils have developed on easy weathered Sarmatian and Palaeogene limestones and those on old flood cones. These soils are with AC-profile, well-formed humus layer with good fine granular structure with different content of rock fragments $[5,14,15]$.

Table 4. Soil properties of Rendiznas - Rendzic Leptosols

\begin{tabular}{|c|c|c|c|c|c|c|c|c|c|c|c|c|}
\hline \multirow[b]{2}{*}{$\begin{array}{c}\text { Horizon } \\
\text { Depth }(\mathrm{cm})\end{array}$} & \multirow{2}{*}{$\begin{array}{c}\text { Soil Color } \\
\text { (Munsell } \\
\text { Color } \\
\text { chart) }\end{array}$} & \multirow{2}{*}{$\begin{array}{c}\mathrm{pH} \\
(\mathrm{KCl})\end{array}$} & \multirow[b]{2}{*}{$\begin{array}{c}\text { SOM } \\
\text { (Humus) } \\
\%\end{array}$} & \multirow[b]{2}{*}{$\begin{array}{c}\text { Total } \\
\mathrm{CaCO}_{3} \\
\%\end{array}$} & \multirow[b]{2}{*}{$\begin{array}{c}\text { Total N } \\
\%\end{array}$} & \multicolumn{7}{|c|}{ Soil Texture - Particle size in mm } \\
\hline & & & & & & $>1$ & $\begin{array}{c}1- \\
0.25\end{array}$ & $\begin{array}{l}0.25- \\
0.05\end{array}$ & $\begin{array}{l}0.05 \\
0.01\end{array}$ & $\begin{array}{l}0.01- \\
0.005\end{array}$ & $\begin{array}{c}0.005- \\
0.001\end{array}$ & $>0.001$ \\
\hline ACk 0-28 & 10 YR 5/2 & 6.8 & 2.68 & 3.64 & 0.124 & 5.1 & 15.5 & 20.4 & 10.7 & 8.8 & 8.7 & 24.1 \\
\hline CRk 28-65 & $10 \mathrm{YR} 5 / 3$ & 7.1 & 1.48 & 20.90 & 0.057 & 47.0 & 10.2 & 11.2 & 4.7 & 3.1 & 4.4 & 7.5 \\
\hline
\end{tabular}

Rendzinas soil texture is usually heavy silty-clay with different contents with chalk rock particles. Lighter texture and with a higher content of skeleton soils, these soils are developed on marbles. Rendzinas are loose, warm and well-aerated soils. A considerable part of them have unfavorable water regime due to their shallow profile. In many places soil cover is eroded or too shallow with rocks on the surface [16].

The average humus content in the surface horizon of arable land in lowland and mountainous areas is 5 to $7 \%$, and at altitudes above 800 meters up to $13.5 \%$. Differences in organic matter content are determined mainly by the altitude and vegetation.

The amount of organic matter decreases rapidly in farmlands. The average content of humus in cultivated lands is $3 \%$.

Carbonate content varied quite widely. The reaction is neutral and slightly alkaline. Rendzinas used mainly pasture plains and mountainous areas where they have greater capacity, are suitable for growing grapes, cherries and more. The main activities for improvement of these soils are to reduce or limit erosion, cleaning of stones and bushes.

\section{Alluvial soils - Haplic Fluvisols [7,8].}

Characterized by the presence only of starting surface horizon (A), which are difficult to distinguish from the soil forming materials. It has little depth and gradually goes down. The individual layers are composed of well-sorted by size material. The color of the soil may be different depending on the materials that are deposited, but most often is yellowish-gray, yellowish-brown or brown. The soil texture structure of alluvial soils is quite different, it can meet all varieties, but most often these soils are sandy loam and sandy. As these soils are more distant from the river bed and the more near the mouth of the river, they have heavier texture. In profile depth soil texture is also very heterogeneous. The chemical composition is also very dependent on the chemical composition of the sediment $[9,7]$.

The humus content is usually low 1 to $2 \%$ (Table 5). The content of total amounts of nitrogen, is different but the amounts of the mobile forms of them are small and they are poorly stocked with nitrogen. On a widespread sandy loam and sandy alluvial soils can be successfully cultivated all major vegetable crops. 


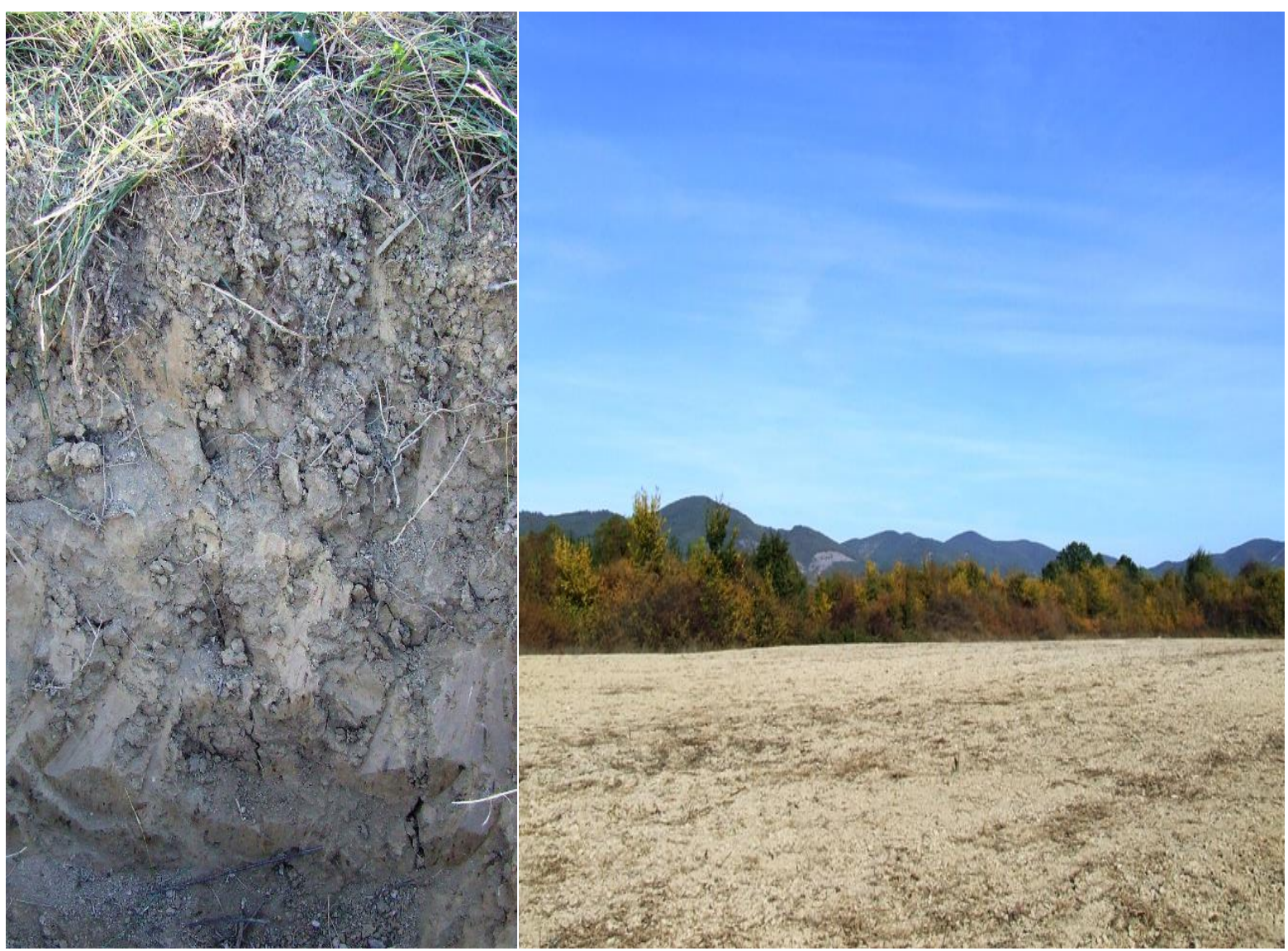

Photo 3. Alluvial soil - Near the Bebresh river - v. Skravena, Botevgrad

Table 5. Soil properties of Haplic Fluvisols

\begin{tabular}{|c|c|c|c|c|c|c|c|c|c|c|c|c|}
\hline \multirow{2}{*}{$\begin{array}{c}\text { Horizon } \\
\text { Depth }(\mathrm{cm})\end{array}$} & \multirow{2}{*}{$\begin{array}{c}\text { Soil Color } \\
\text { (Munsell } \\
\text { Color } \\
\text { chart) }\end{array}$} & \multirow{2}{*}{$\underset{(\mathrm{KCl})}{\mathrm{pH}}$} & \multirow{2}{*}{$\begin{array}{c}\text { SOM } \\
\text { (Humus) } \\
\%\end{array}$} & \multirow{2}{*}{$\begin{array}{c}\text { Total } \\
\mathrm{CaCO}_{3} \\
\%\end{array}$} & \multirow[b]{2}{*}{$\begin{array}{c}\text { Total N } \\
\%\end{array}$} & \multicolumn{7}{|c|}{ Soil Texture - Partical size in $\mathrm{mm}$} \\
\hline & & & & & & $>1$ & $\begin{array}{c}1- \\
0.25\end{array}$ & $\begin{array}{c}0.25- \\
0.05\end{array}$ & $\begin{array}{c}0.05- \\
0.01\end{array}$ & $\begin{array}{l}0.01- \\
0.005\end{array}$ & $\begin{array}{c}0.005- \\
0.001\end{array}$ & $\begin{array}{c}> \\
0.001\end{array}$ \\
\hline Ap 0-29 & $10 \mathrm{YR} 3 / 3$ & 4.2 & 1.69 & 0.0 & 0.088 & 22.0 & 5.5 & 24.2 & 26.0 & 7.9 & 6.3 & 7.8 \\
\hline C1 29-58 & 10 YR 5/3 & 5.2 & 0.42 & 0.0 & 0.022 & 42.5 & 31.0 & 15.2 & 4.9 & 2.4 & 2.2 & 1.5 \\
\hline C2 58-94 & $10 \mathrm{YR} 5 / 3$ & 5.9 & 0.28 & 0.0 & - & 70.5 & 21.5 & 3.3 & 1.2 & 0.7 & 0.1 & 0.8 \\
\hline C3 94- 150 & $10 \mathrm{YR} 4 / 4$ & 5.8 & 0.37 & 0.0 & - & 76.0 & 21.8 & 1.2 & 0.4 & 0.1 & 0.1 & 0.3 \\
\hline
\end{tabular}

Alluvial meadow soils - Mollic Fluvisols [7,8].

Alluvial meadow soils are located on the floodplains of the river Bebresh and its tributaries Lakavitsa, Bogovinje, Rudarka, Old River etc. In the spring the water level rises significantly, the soils are flooded almost every year. Soil forming materials are river sediments.
Alluvial meadow soils are characterized by slow soil formation process. Their profile is represented by the surface humus layer with a thickness from 10 to 40 $\mathrm{cm}$, under which follow unaffected alluvial deposits. Depending on the degree organic matter content the color varies from dark gray to yellow-grey (Table 6). Uncultivated surface humus horizon is usually with fine granular structure. 
Table 6. Soil properties of Alluvial medow soil - Mollic Fluvisols (WRB, 2014)

\begin{tabular}{|c|c|c|c|c|c|c|c|c|c|c|c|c|}
\hline \multirow[b]{2}{*}{$\begin{array}{l}\text { Horizon } \\
\text { Depth }(\mathrm{cm})\end{array}$} & \multirow{2}{*}{$\begin{array}{c}\text { Soil Color } \\
\text { (Munsell } \\
\text { Color } \\
\text { chart) }\end{array}$} & \multirow[b]{2}{*}{$\begin{array}{l}\mathrm{pH} \\
(\mathrm{KCl})\end{array}$} & \multirow{2}{*}{$\begin{array}{c}\text { SOM } \\
\text { (Humus) } \\
\%\end{array}$} & \multirow{2}{*}{$\begin{array}{c}\text { Total } \\
\mathrm{CaCO}_{3} \\
\%\end{array}$} & \multirow[b]{2}{*}{$\begin{array}{c}\text { Total N } \\
\%\end{array}$} & \multicolumn{7}{|c|}{ Soil Texture - Particle size in $\mathrm{mm}$} \\
\hline & & & & & & $>1$ & $\begin{array}{c}1- \\
0.25\end{array}$ & $\begin{array}{c}0.25- \\
0.05\end{array}$ & $\begin{array}{c}0.05- \\
0.01\end{array}$ & $\begin{array}{l}0.01- \\
0.005\end{array}$ & $\begin{array}{c}0.005- \\
0.001\end{array}$ & $\begin{array}{c}> \\
0.001\end{array}$ \\
\hline Ap. 0- 30 & $10 \mathrm{YR} 4 / 3$ & 3.9 & 3.02 & 0.0 & 0.159 & 12.7 & 13.4 & 14.8 & 21.6 & 12.0 & 14.2 & 11.1 \\
\hline $\mathrm{AC} 1$ & $10 \mathrm{YR} 6 / 2$ & 3.8 & 0.96 & 0.0 & 0.068 & 9.8 & 17.2 & 17.3 & 19.4 & 10.8 & 13.5 & 11.5 \\
\hline C1 45-65 & 10 YR 5/3 & 3.9 & 0.71 & 0.0 & - & 6.3 & 21.7 & 22.2 & 18.1 & 11.8 & 8.8 & 10.3 \\
\hline C2 65-87 & $\mid 10$ YR 5/3 & 4.0 & 0.66 & 0.0 & - & 6.7 & 14.5 & 25.0 & 20.2 & 11.0 & 10.5 & 11.4 \\
\hline C3 87-122 & 10 YR $4 / 4$ & 5.3 & 0.73 & 0.0 & - & 0.0 & 3.1 & 21.4 & 22.8 & 16.9 & 16.2 & 19.3 \\
\hline C4122-157 & 10 YR 5/4 & 5.6 & 0.68 & 0.0 & - & 0.0 & 0.0 & 8.2 & 32.0 & 17.4 & 17.4 & 20.5 \\
\hline
\end{tabular}

The soil texture of the alluvial meadow soil depends entirely on the composition of river sediments on which they are formed. Due to the significant variety of the same in terms of their horizontal distribution and depth there are big variety of soil texture and structure in depth of the profile. Usually dominate the sandy varieties sandy - loam and sandy-clay textural classes. Alluvial soils are with good air properties and warm (except those with very high groundwater level). Alluvial meadow soils are with average water holding capacity and high water permeability.

Soil organic matter content in the surface horizon varies within a broad range - from 1 to $5 \%$ in the pastures and from 1 to $2 \%$ in the cultivated land. The amount of total nitrogen ranges from 0.04 to $0.30 \%$. The conditions for the mobilization of organic nitrogen are good. The soil pH is slightly acidic to neutral [10].
The majority of these soils have of high fertility. Alluvial meadow soils are used mainly for vegetable crops. They are suitable also for growing fodder, technical and fruit crops. Alluvial meadow soils formed on granite alluvium are poor in nutrients [17].

Diluvial soils - Colluvic Regosols $[7,8]$.

These soils occupy diluvial, colluvial and proluvial loops at the foot of the slopes. Diluvial soils formation process is interrupted frequently by deposition of new materials. Diluvial soils. This is a term generally applied to accumulations of sand and gravel which are found in various parts of the kingdom, and which appear to have been deposited by water, but which have never hardened into the consistency of rocks [18].

The soil texture varies within a large range sandy, loamy, sandy-loam. Diluvial soils are structureless. These soils are loose, well aerated, low water retention and high-water permeability [19].

Table 7. Soil properties of Diluvial soils - Colluvic Regosols.

\begin{tabular}{|c|c|c|c|c|c|c|c|c|c|c|c|c|c|}
\hline $\begin{array}{c}\text { Horizon } \\
\text { Depth } \\
(\mathrm{cm})\end{array}$ & $\begin{array}{c}\text { Soil Color } \\
(\text { Munsell) }\end{array}$ & $\begin{array}{c}\mathrm{pH} \\
(\mathrm{KCl})\end{array}$ & $\begin{array}{c}\text { SOM } \\
(\mathrm{Humus}) \\
\%\end{array}$ & $\begin{array}{c}\text { Total } \\
\mathrm{CaCO}_{3} \\
\%\end{array}$ & \multicolumn{2}{|c|}{$\begin{array}{c}\text { Total N } \\
\%\end{array}$} & \multicolumn{6}{|c|}{ Soil Texture - Particle size in mm } \\
\hline Ap 0- 29 & 10 YR 5/4 & 4.4 & 1.39 & 0.0 & & 0.095 & 12.5 & 22.4 & 18.6 & 18.0 & 9.1 & 8.2 & 10.4 \\
\hline C1 29 -56 & 10 YR 5/4 & 4.8 & 0.97 & 0.0 & & 0.095 & 7.7 & 24.6 & 17.9 & 19.1 & 7.9 & 8.4 & 13.6 \\
\hline C1 56-89 & 10 YR 5/4 & 4.7 & 0.92 & 0.0 & & - & 6.3 & 21.2 & 20.0 & 14.6 & 8.3 & 5.1 & 23.5 \\
\hline C2 89-120 & 10 YR 5/4 & 4.6 & 0.64 & 0.0 & & - & 7.9 & 25.6 & 24.7 & 10.5 & 6.2 & 5.5 & 18.7 \\
\hline $\begin{array}{c}\text { C3 120 - } \\
154\end{array}$ & 10 YR 5/4 & 4.5 & 0.71 & 0.0 & & - & 4.2 & 32.6 & 19.7 & 14.9 & 2.9 & 7.3 & 17.5 \\
\hline
\end{tabular}

The content of humus in diluvial soil is low from 0.5 to $2 \%$ (Table 7 and 8 ). In depth of the profile, the amount is reducing. content of total nitrogen - of 0.08 to $0.18 \%$. The conditions for the mobilization of organic nitrogen are good. Diluvial soils formed of silicate rocks are non-carbonate, and other fored on calcareous sedimentary rock [21]. The soil reaction is neutral or slightly alkaline. These soils are very suitable for growing some fruit trees, especially walnuts, cherries and more. Diluvial soils are, generally speaking, remarkable for their poverty, but under proper management most of them may be made productive. They react very well to organic and mineral fertilizers. 


\section{Diluvial soil - Sckeletic Collvic Regosols [7,8].}

Table 8. Soil properties of Diluvial soils - Sckeletic Colluvic Regosols

\begin{tabular}{|c|c|c|c|c|c|c|c|c|c|c|c|c|}
\hline \multirow[b]{2}{*}{$\begin{array}{c}\text { Horizon } \\
\text { Depth }(\mathrm{cm})\end{array}$} & \multirow[b]{2}{*}{$\begin{array}{l}\text { Soil Color } \\
\text { (Munsell) }\end{array}$} & \multirow[b]{2}{*}{$\begin{array}{c}\mathrm{pH} \\
(\mathrm{KCl})\end{array}$} & \multirow{2}{*}{$\begin{array}{c}\text { SOM } \\
\text { (Humus) } \\
\%\end{array}$} & \multirow{2}{*}{$\begin{array}{c}\text { Total } \\
\mathrm{CaCO}_{3} \\
\%\end{array}$} & \multirow[b]{2}{*}{$\begin{array}{c}\text { Total } \mathrm{N} \\
\%\end{array}$} & \multicolumn{7}{|c|}{ Soil Texture - Particle size in mm } \\
\hline & & & & & & $>1$ & $\begin{array}{c}1- \\
0.25\end{array}$ & $\begin{array}{l}0.25- \\
0.05\end{array}$ & $\begin{array}{l}0.05- \\
0.01\end{array}$ & $\begin{array}{l}0.01- \\
0.005\end{array}$ & $\begin{array}{l}0.005- \\
0.001\end{array}$ & $>0.001$ \\
\hline Ap 0-29 & 10 YR $5 / 3$ & 5.1 & 0.54 & 0.0 & 0.051 & 27.1 & 15.6 & 14.7 & 19.4 & 8.1 & 6.5 & 8.0 \\
\hline C1 $29-50$ & 10 YR 5/4 & 4.7 & 0.50 & 0.0 & 0.083 & 29.2 & 10.2 & 13.7 & 17.0 & 10.6 & 9.3 & 9.5 \\
\hline C1 50-84 & $10 \mathrm{YR} 5 / 4$ & 4.9 & 0.52 & 0.0 & - & 33.0 & 16.6 & 11.9 & 17.0 & 7.4 & 6.1 & 7.8 \\
\hline C2 84-114 & $10 \mathrm{YR} 5 / 4$ & 4.9 & 0.36 & 0.0 & - & 41.1 & 14.9 & 9.4 & 13.6 & 8.7 & 4.9 & 7.1 \\
\hline C3 $114-150$ & $10 \mathrm{YR} 5 / 4$ & 5.0 & 0.17 & 0.0 & - & 50.8 & 15.8 & 9.3 & 10.1 & 5.3 & 3.7 & 4.8 \\
\hline
\end{tabular}

Shallow soils Lithosols - Leptosols [7,8].

Shallow and underdeveloped Lithosols are widely available. Are formed on reddish brown quaternary materials. Characterized by the presence of many skeletal particles. They are poor in nutrients. Their soil cover is shallow and heavily eroded, cut by deep ditches, ravines and valleys.

Table 9. Soil properties of Shallow soils, Lithosols - Leptosols.

\begin{tabular}{|c|c|c|c|c|c|c|c|c|c|c|c|c|}
\hline \multirow[b]{2}{*}{$\begin{array}{c}\text { Horizon } \\
\text { Depth }(\mathrm{cm})\end{array}$} & \multirow[b]{2}{*}{$\mid \begin{array}{l}\text { Soil Color } \\
\text { (Munsell) }\end{array}$} & \multirow[b]{2}{*}{$\begin{array}{c}\mathrm{pH} \\
(\mathrm{KCl})\end{array}$} & \multirow{2}{*}{$\begin{array}{c}\text { SOM } \\
\text { (Humus) } \\
\%\end{array}$} & \multirow{2}{*}{$\begin{array}{c}\text { Total } \\
\mathrm{CaCO}_{3} \\
\%\end{array}$} & \multirow[b]{2}{*}{$\begin{array}{c}\text { Total N } \\
\%\end{array}$} & \multicolumn{7}{|c|}{ Soil Texture - Particle size in $\mathrm{mm}$} \\
\hline & & & & & & $>1$ & $\begin{array}{c}1- \\
0.25\end{array}$ & $\begin{array}{l}0.25- \\
0.05\end{array}$ & $\begin{array}{l}0.05- \\
0.01\end{array}$ & $\begin{array}{l}0.01- \\
0.005\end{array}$ & $\begin{array}{l}0.005- \\
0.001\end{array}$ & $>0.001$ \\
\hline AC $0-22$ & $10 \mathrm{YR} 5 / 3$ & 4.5 & 1.85 & 0.0 & 0.073 & 45.0 & 36.2 & 2.4 & 6.6 & 2.7 & 2.9 & 3.3 \\
\hline R 24 & - & - & - & - & - & - & - & - & - & - & - & - \\
\hline
\end{tabular}

Lithosols are characterized by shallow profile A - R or AC - R. They have a very shallow fragmented horizon which lies over hard rock (Table 9). Rock fragments with size of 5 to $7.5 \mathrm{~cm}$ reaches $50-70 \%$ of the soil mass. The content of clay and silt is usually low.
Lithosols formed on calcareous rocks have a heavier soil texture [20]. The organic matter and nutrients content is poor. They have low water capacity and high permeability.

Table 10. Distribution of soils in Botevgrad valley in hectares and \%

\begin{tabular}{|c|c|c|}
\hline Soil type / land & Area (ha) & $\%$ \\
\hline Alluvial (diluvial) soils & 4626 & 32.3 \\
\hline Shallow soils - Lithosols & 2282 & 16 \\
\hline Gray forest soils & 1547 & 11 \\
\hline Diluvial soils & 1539 & 11 \\
\hline Diluvial meadow soils & 1322 & 9 \\
\hline Light gray forest soils & 510 & 3.6 \\
\hline Alluvial meadow soils & 197 & 1.3 \\
\hline Rendzinas & 135 & 0.9 \\
\hline Dark gray forest soils & 31 & 0.2 \\
\hline Sands and gravel & 108 & 0.7 \\
\hline Rocks and gullies & 693 & 4.8 \\
\hline Water areas & 26 & 0.2 \\
\hline Urban areas (villages) & 1312 & 9 \\
\hline Total & $\mathbf{1 4 3 2 7}$ & $\mathbf{1 0 0 \%}$ \\
\hline
\end{tabular}




\section{Distribution of land cover in Botevgrad valley}

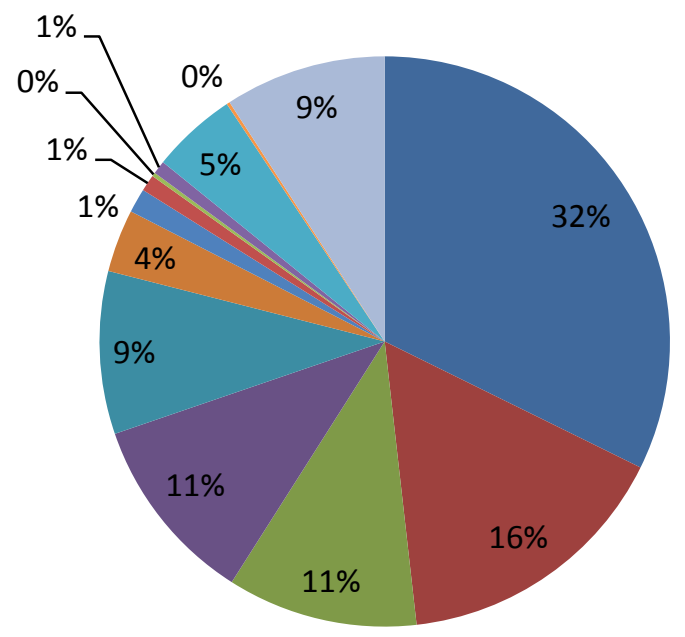

Alluvial (diluvial) soils

- Shallow soils - Lithosols

Gray forest soils

- Diluvial soils

- Diluvial meadow soils

- Light gray forest soils

Alluvial meadow soils

Rendzinas

Dark gray forest soils

- Sands and gravel

Fig 3. Land cover in Botevgrad valley (\%)

\section{CONCLUSION}

In Botevgrad valley most common soil type is Alluvial (diluvial) meadow soil, that occupies about $32.3 \%$ of the total area or 4626 ha. This is almost one third of the entire area. Typically for this hillymountain region are shallow soils or Lithosols with area about $16 \%$, which are generally located on sloping eroded areas (2282 ha). Alluvial and Diluvial meadow soils have similar areas 1500 and 1322 ha. Close to the small, rivers in the valley are spread alluvial soils, which occupy area of $1.3 \%$ or 197 ha. The Gray forest soils are about $11 \%$ or 1547 ha, and Light gray forest soils are only about $3.6 \%$. These tow soil types are more common in Fore-Balkan area. Rendzinas are distributed mainly in the northern part of the valley mainly on the limestone and other carbonate rocks with an area of about 135 ha or $0.9 \%$. The most fertile soils Dark Gray forest soils are only 31 ha or $0.2 \%$ of the valley. Arable lands for cultivation and pastures are about $68.4 \%$, other $22 \%$ can be used for forestry. Settlements, industrial zones and other infrastructure occupy $9 \%$.

\section{REFERENCES:}

1. Geography of Bulgaria, Physical and socioeconomic geography (Collective to the Geographical Institute at BAS). ISBN -9544641238. Ed. For-Kom, 2002, 760 (in Bulgarian)
2. Bulgarian

Encyclopedia,

Large Encyclopedia Bulgaria. Vol. 1. Sofia, Trud Book Publishing House, ISBN 9789548104234, 2011, pp. 345 - 346. (in Bulgarian)

3. Dotseva, Z., D. Vangelov, I. Gerdjikov, The Botevgrad basin main characteristics and evolution. Geologica Balcanica, 47 (2), Sofia, 2018, pp. 47 58.

4. Haji-Yanakiev, A., Soil characteristics of the land in APC "Pravets" Sofia region. Soil database archive of ISSAPP "N. Poushkarov", 1986. (in Bulgarian)

5. Haji-Yanakiev, A. Soil characteristics of the land in the APC "Botevgrad", Sofia district. Soil database archive of ISSAPP "N. Poushkarov", 1983. (in Bulgarian)

6. Haji-Yanakiev, A. Soil characteristics of the land in APC "Litakovo" Sofia region. Soil database archive of ISSAPP "N. Poushkarov", 1988. (in Bulgarian)

7. Penkov, M., V. D. Donov, T. Boyadjiev, T. Andonov, N. Ninov, M. Yolevski, G. Andonov, S. Gencheva, Classification and Diagnostic of Bulgarian soils Related with Land Reform, Zemizdat, Sofia, 1992, pp. 151.

8. IUSS Working Group, World reference base for soil resources International soil classification system for naming soils and creating legends for soil maps. World Soil Resources Reports No. 106. FAO, 
Rome, Italy, 2014.

9. Koinov, V., G. Gurov, B., Kolcheva. Soil Science, Zemizdat Sofia, 1980, p. 284. (in Bulgarian)

10. Buchvarova S., B. Georgiev, M. Teoharov A. Samlieva, V. Krasteva, North Agrotehpark B: Assessment of agro-ecological potential within the agro-parks in the country optimize the structure of agricultural production, Scientific works of NATSAN, Vol. 2, 2005, 5 - 52 p. (in Bulgarian)

11. Goleva A., V. Ilinkin, Investigation on Gray Forest Soils in the Ludogorie Region. XXIV International Scientific Conference for Young Scientists, Rousse, ISSN 954-323-057-9, 2015, 13 - 20p. (in Bulgarian)

12. Donov V., Forest soil science. Martilen Publishing House, 1993, p. 430. (in Bulgarian)

13. Shishkov, T., Kolev, N. The Soils of Bulgaria, Springer, ISBN 978-94-007-7784-2, 2014, 208 p. DOI http://doi.org/10.1007/978-94-007-7784-2.

14. Bogdanov, S., S. Savev, E. Tsavkov, Investigation on humus-carbonate soils in the Western Balkan Mountains foothill. Environmental engineering and environmental protection. Issue 3, 2015, pp. $29-35$.

15. Malinova, L., D. Karatoteva. Cation exchange properties of soils from carbonate landscape in the "Central Balkan" national park.
Bulgarian Journal of Agricultural Science. 22 (6), 2016. 728 - 732p.

16. Ilinkin, V., S. Bogdanov, A. Goleva, Characteristics of Rendzinas in the Ludogorie Region. Bulgarian Journal of Soil Science, 2(1), 2017, 32 - 41. DOI: http://doi.org/10.5281/zenodo.2585635

17. Koinov, V., I. Kabakchiev, K. Boneva, Atlas of the soils in Bulgaria. Zemizdat, Sofia, Bulgaria, 1998. (in Bulgarian)

18. Gurov G., N. Artinova, Soil Science, ed. Intelekspert-94, Plovdiv, 2015, 257 p. (in Bulgarian)

19. Ilinkin, V., Dimitrov D., Zhelev P., Characteristics of Fluvisols in sand and gravel deposit "Kriva bara", Sofia, Bulgaria, Ecological Engineering and Environment Protection, No 1, 2018, p. $58-65$.

20. Andreeva, N., B. Hristov, P. Petrov, Comparative characteristics of primitive soils on different geological materials in Bulgaria. Anniversary of Sofia University, Faculty of Geology and Geography, Book. 1 - Geology / Vol. 1, 2015, 113 122. (in Bulgarian)

21. Malinova, L., K. Petrova, P. Karmazova, Results of soil monitoring in the Western Balkan mountain, „,90 Years Forest Research Institute - for the Society and Nature" - Proceeding, at Sofia, 2018 , p. $208-216$.

\section{*Coresspondig Author: Assosiated professor Biser Hristov}

Univesity of Forestry

10 Kl. Ohridski Blvd.,

Sofia, Bulgaria

mobile: +359887808397

e-mail: bisseru@gmail.com 